\title{
The Effects of Southern Hemisphere Crop Production on Trade, Stocks, and Price Integration
}

\author{
Joseph W. Glauber and Mario J. Miranda
}

\subsection{Introduction}

The past 35 years have witnessed a rapid expansion of grain and oilseed production in the southern hemisphere, particularly in South America. Expanded land use and increased productivity have propelled southern hemisphere exports from accounting for about $20 \%$ of world soybean exports in 1980 to over $50 \%$ in 2010 (Fig. 4.1). Over the same period, southern hemisphere maize exports grew from 18 to $33 \%$ and wheat exports from 15 to $25 \%$. Over this period, Brazil has become the world's largest soybean exporter and the second-largest maize exporter.

Projected grain and oilseed trends by various forecasters (USDA 2015; FAPRI 2014; FAO-OECD 2014) point to expected continued growth by southern hemisphere producers over the next 10 years. Moreover, to meet world food needs by 2050, FAO concludes that much of the needed production gains will have to come from South America and sub-Saharan Africa where there remain potential supplies of arable land and where yields lag potential (Bruinsma 2011; Alexandratos and Bruinsma 2012).

The growth of southern hemisphere production is significant, not only for the increased supplies to meet world food needs but also because it effectively shortens the crop growing cycle by 6 months. Since production seasons for most grains

\section{J.W. Glauber $(\triangle)$}

International Food Policy Research Institute (IFPRI), Washington, DC, USA

e-mail: J.Glauber@cgiar.org

M.J. Miranda

Ohio State University, Columbus, OH, USA 


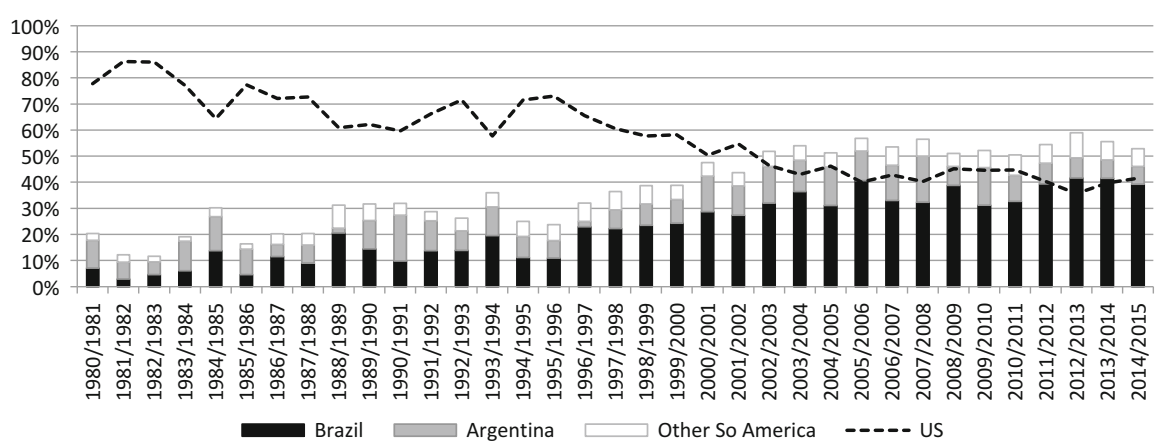

Fig. 4.1 Share of global soybean exports. Source: US Department of Agriculture Production, Supply, and Distribution Database

and oilseeds are largely counter-seasonal to the northern hemisphere, southern hemisphere producers can react rapidly to production shortfalls in the northern hemisphere. For example, in response to the widespread North American drought in the summer of 2012, Brazilian producers planted a record of 15.8 million hectares of maize, which provided needed supplies to a tight world market and helped to reduce price volatility.

What is less well understood, however, is the effect of the growth of southern hemisphere production on trade, inventories, and pricing. For example, how do shifts in production and consumption affect intraseasonal patterns of trade between the northern and southern hemispheres? Are there stronger incentives to hold stocks in one hemisphere and does this vary seasonally? How are seasonal price patterns affected in importing and exporting countries when the share of production and consumption shifts between hemispheres? Lastly, how closely are prices integrated between exporting and importing markets when new supplies are available to the market every 6 months?

Our objective is to gain a clearer understanding of how cross-hemispheric shifts in agricultural production over the past two decades have affected trade patterns, global price relationships, and stockholding. In our running example, the commodity is soybean, and the major producer-exporters are the USA and South America (Brazil and Argentina).

\subsection{The Model}

Consider a storable agricultural commodity called "beans." The global bean market consists of two major exporting countries $(i=1,2)$ and the rest of the world or, more simply, the "world market" $(i=0)$. Beans are produced, consumed, and stored 
in the two exporting countries. Although production and stockholding may occur in the rest of the world, the rest of the world is treated as a net consumer of the exports generated by the exporters.

Time $t$ is measured not in years but in semiannual periods. Harvesting occurs in the period after planting. Exporter $i=1$ plants in odd periods and harvests in the subsequent even period; exporter $i=2$ plants in even periods and harvests in the subsequent odd period. The model is driven by a single exogenous random variable $\widetilde{y}_{t i}$ and random new production in period $t$ in exporting country $i$. Since planting periods alternate between the two exporting countries, $\widetilde{y}_{i t}$ is zero if $i=1$ and $t$ is odd or if $i=2$ and $t$ is even.

The model features the following endogenous variables: $p_{t i}$, market price, year $t$, region $i=0,1,2 ; c_{t i}$, consumption, year $t$, country $i=1,2 ; q_{t i}$, availability at beginning of year $t$, country $i=1,2 ; x_{t i}$, exports to the world market, year $t$, country $i=1,2$; and $z_{t i}$, ending stocks, year $t$, country $i=1,2$. Market equilibrium is governed by the following six sets of relations:

Material Balance. Each period $t$ begins with predetermined quantities of beans available in each of the two exporting countries; these quantities must either be consumed, exported, or stored:

$$
q_{t i}=c_{t i}+x_{t i}+z_{t i}, i=1,2 .
$$

Trade Balance. Total exports to the world market must meet the demand for imports in the rest of the world at the equilibrium world price:

$$
x_{t 1}+x_{t 2}=\alpha_{0}-\beta_{0} p_{t 0} .
$$

Here, $\alpha_{0}>0$ and $\beta_{0}>0$.

Regional Demand. The quantities consumed in each of the exporting countries must meet the demand for consumption in those countries at the local equilibrium prices:

$$
c_{t i}=\alpha_{i}-\beta_{i} p_{t i}, i=1,2, .
$$

Here, $\alpha_{i}>0$ and $\beta_{i}>0$.

Spatial price equilibrium. Competition among profit-maximizing exporters guarantees that arbitrage profit opportunities from exporting are eliminated in each of the exporting countries:

$$
x_{t 0} \geq 0 \perp p_{t 0} \leq p_{t i}+\tau_{i}, i=1,2 .
$$

Here, $\tau_{i}$ indicates the unit cost of exporting to the rest of the world from country $i=1,2$. Also, the symbol $\perp$ indicates that both inequalities must hold and at least one must hold with equality. 
Intertemporal Price Equilibrium. Competition among expected profitmaximizing storers guarantees that expected arbitrage profit opportunities from storing are eliminated in the exporting countries:

$$
z_{t i} \geq 0 \perp \delta E_{t} p_{t+1, i} \leq p_{t i}+\kappa_{i}, i=1,2 .
$$

Here, $\kappa_{i}$ indicates the unit cost of storing between periods in country $i=1,2$ and $\delta$ is the biannual discount factor.

Availability. The quantities available at the beginning of next period in each of the exporting countries equal the sum of the quantities stored in the current period and new production:

$$
q_{t+1,1}=\left\{\begin{array}{cc}
z_{t 1}+\widetilde{y}_{t+1,1} & t \text { odd } \\
z_{t 1} & t \text { even }
\end{array}\right.
$$

and

$$
q_{t+1,2}=\left\{\begin{array}{cc}
z_{t 2} & t \text { odd } \\
z_{t 2}+\widetilde{y}_{t+1,2} & t \text { even. }
\end{array}\right.
$$

We assume that the model is annually stationary. That is, although model parameters may vary across semiannual periods within years, they do not vary from year to year. We also assume that new productions are serially and spatially uncorrelated, stationary, and lognormal distributed with means $\bar{y}_{i}>0$ and standard deviations $\sigma_{i}>0$ in the country $i=1,2$.

\subsection{Numerical Solution Strategy}

Under the specified assumptions, equilibrium market prices are functions of the availabilities in the two exporting countries:

$$
p_{t i}=\left\{\begin{array}{l}
f_{1 i}\left(q_{t 1}, q_{t 2}\right), t \text { odd } \\
f_{2 i}\left(q_{t 1}, q_{t 2}\right), t \text { even }
\end{array}, i=0,1,2\right.
$$

so that under rational expectations,

$$
E_{t} p_{t+1, i}=\left\{\begin{array}{l}
E_{\tilde{y}_{1}} f_{2 i}\left(z_{t 1}+\widetilde{y}_{1}, z_{t 2}\right), t \text { odd } \\
E_{\tilde{y}_{2}} f_{1 i}\left(z_{t 1}, z_{t 2}+\widetilde{y}_{2}\right), t \text { even. }
\end{array}, i=1,2 .\right.
$$


The equilibrium price functions $f$ are characterized by a system of functional equations that do not possess a known closed-form solution. However, the price functions may be computed to any desired degree of accuracy using collocation methods for standard functional equations. In particular, we construct finitedimensional approximations of the form

$$
f_{i}\left(q_{1}, q_{2}\right) \approx \sum_{j=1,2, \ldots, n} c_{i j} \phi_{j}\left(q_{1}, q_{2}\right)
$$

for $i=0,1,2$, where the $c_{i j}$ are a set of $3 n$ coefficients to be determined and the $\phi_{j}$ are cubic spline basis functions. The coefficients are fixed by requiring the price function approximants to satisfy the equilibrium conditions, not at all possible points in their domain, but rather at $n$ prescribed collocation nodes. This poses a finite-dimensional root-finding problem that may be solved using standard nonlinear equation methods, such as the Newton's method or function iteration (see Miranda and Fackler 2002).

\subsection{Model Simulations}

The global market is simulated using Monte Carlo methods to assess the impact of key model parameters on the performance of key model variables. Generally speaking, we are interested in the effects of (a) shifts in global production, (b) changes in market integration, and (c) synchronicity of production on intra- and interannual price variability and stockholding.

Our simulations are designed to address two major questions. First, how does producing half of the world's yearly bean output in period 1 and half in period 2 affect carryout compared to a world where most of the bean production takes place in one period or the other? Presumably, if production is split equally between periods (and thus equally between exporting countries), carryout in the exporting country would be lower during the harvest period than if the country were the dominant producer. Second, how does this scenario affect inter-seasonal price differences? With one dominant producer, inter-seasonal price differences show full carrying charges. Does this hold when both countries are of the same size or will bean prices in one country rise only to fall when the harvest from the other country enters the market?

Base case model parameters are initially calibrated to reflect the global soybean market conditions in 2014 with quantities and prices normalized to 1 (see Table 4.1). More specifically, in the model, expected annual world production equals 1 , and total annual world demand at a price of 1 equals 1 . The semiannual discount factor $\delta$ is assumed to equal 0.975 .

Table 4.2 shows the average soybean production, consumption, and exports during the periods 1990-1994, 2000-2004, and 2010-2014. In addition, it shows the average production, consumption, and exports in the period 2020-2024; these figures are obtained through simulation under expected prevailing conditions 
Table 4.1 Base case parameters

\begin{tabular}{l|c|c|l}
\hline Parameter & USA & $\begin{array}{l}\text { South } \\
\text { America }\end{array}$ & $\begin{array}{l}\text { Rest of the } \\
\text { world (ROW) }\end{array}$ \\
\hline$A_{1990-2004}$ & 0.163 & 0.117 & 0.220 \\
\hline$A_{2000-2004}$ & 0.130 & 0.144 & 0.260 \\
\hline$A_{2010-2014}$ & 0.093 & 0.152 & 0.255 \\
\hline$A_{2020-2024}$ & 0.079 & 0.159 & 0.263 \\
\hline$\beta$ & -0.20 & -0.20 & -0.25 \\
\hline$\sigma_{d}$ & 0.10 & 0.10 & 0.10 \\
\hline$K$ & 0.01 & 0.01 & - \\
\hline$\tau$ & 0.15 & 0.15 & - \\
\hline$y_{1990-1994}$ & 0.489 & 0.301 & 0.210 \\
\hline$y_{2000-2004}$ & 0.396 & 0.441 & 0.163 \\
\hline$y_{2010-2014}$ & 0.333 & 0.507 & 0.160 \\
\hline$y_{2020-2024}$ & 0.295 & 0.575 & 0.130 \\
\hline$\sigma_{y}$ & 0.18 & 0.18 & - \\
\hline
\end{tabular}

Table 4.2 Production and consumption shares in the four scenarios

\begin{tabular}{l|c|c|c|c}
\hline & $1990-1994$ & $2000-2004$ & $2010-2014$ & $2020-2024$ \\
\hline Global production (mil tonnes) & 116.8 & 192.1 & 274.3 & 344.2 \\
\hline Global consumption (mil tonnes) & 116.6 & 188.1 & 265.8 & 342.6 \\
\hline Share of global production & 48.9 & 39.6 & 33.3 & 29.5 \\
\hline USA (\%) & 30.8 & 45.2 & 52.3 & 57.5 \\
\hline South America (\%) & 20.3 & 15.2 & 14.3 & 13.0
\end{tabular}

Share of global consumption

\begin{tabular}{l|l|l|l|l}
\hline USA (\%) & 32.5 & 25.9 & 18.6 & 15.7 \\
\hline South America (\%) & 24.2 & 30.1 & 31.7 & 31.8 \\
\hline ROW (\%) & 43.2 & 44.0 & 49.7 & 52.5 \\
\hline
\end{tabular}

Production as a percent of consumption

\begin{tabular}{l|r|r|c|c}
\hline USA (\%) & 150.4 & 156.2 & 184.8 & 188.9 \\
\hline South America (\%) & 127.2 & 153.1 & 170.4 & 181.6 \\
\hline ROW (\%) & 47.2 & 35.3 & 29.7 & 24.8 \\
\hline
\end{tabular}

Source: USDA, PSD Database, and ERS. 2015 International Long-Term Projection to 2024

according to the US Department of Agriculture's International Baseline Projections (2015).

Three major trends have characterized the soybean market over the past 20 years. First, production and consumption have expanded rapidly. Over the period 19901994 to 2010-2014, global soybean production and consumption increased by over $4 \%$ per year. Over the next 10 years, soybean production and consumption growth is expected to decline to about $2.5 \%$ annually, even though the figure is still strong compared to growth rates of other grains.

Second, the growth in soybean production has occurred largely in South America. While the USA accounted for almost half of the world's soybean production during 
the period 1990-1994, by 2010-2014, it accounted for only about one-third of the global production. Over the same period, South American production rose from $30.8 \%$ of the global production in 1990-1994 to over $52 \%$ in 2010-2014. Production in the rest of the world (ROW) fell from about $20 \%$ of global production in 1990-1994 to about $14 \%$ in 2010-2014.

Lastly, growth in soybean consumption has occurred largely in South America and ROW. The US share of global soybean consumption fell from $32.5 \%$ in 1990 1994 to less than $19 \%$ in 2010-2014. During the same period, the ROW's share of the global consumption grew, and its share of global production declined, causing the self-sufficiency rate (production divided by consumption) of the ROW to fall from $47 \%$ in to under $30 \%$.

In the simulations that follow, we consider four stylized scenarios corresponding to historical production and consumption shares for the three regions. In the first scenario ("1990-1994"), global production shares were calibrated to reflect 19901994 historical levels where roughly $49 \%$ of the world's soybeans were produced in the USA and $31 \%$ in South America. In the "2000-2004" scenario, the global share of the US production declined to $40 \%$, while South America accounted for $45 \%$ of the world's production. In the "2010-2014" scenario, soybean production in the USA accounted for about $33 \%$ of global production, while soybean production in South America rose to $52 \%$. Lastly, we consider a scenario taken from the US Department of Agriculture's 10-year agricultural baseline projections ("2020 2024 "), in which the US share of global production is projected to be $30 \%$, while the South American share is projected at $58 \%$ (USDA 2015). While simulations under these stylized scenarios should not be interpreted as historical, they are structured to reflect the growth of South American soybean production so as to simulate the impact of that growth on global trade flows, inventory, and pricing relationships.

\subsection{Impact of Shifting Production on Trade}

Table 4.3 shows the simulated effects of shifts in regional production and consumption on seasonal trade flows between the USA and South America and the ROW. As production shifts to South America, trade shifts as well. In the 1990-1994 scenario, in which US soybean production accounted for about $49 \%$ of the global production, the global share of US exports amounted to almost $71 \%$. As production shifts to South America, the US production share falls to about $30 \%$ by $2020-2024$ and the export share falls to about $35 \%$.

Over the same period, as soybean consumption grew faster than production in the ROW, imports from the two major production regions to the ROW grew as well, and the imports are higher in fall. Our highly stylized model assumed that the ROW consumes its domestic production prior to importing. ${ }^{1}$ As self-sufficiency rates fall

\footnotetext{
${ }^{1}$ In reality, many importing countries import year round due to insufficient domestic production, high transportation costs, or other factors.
} 
Table 4.3 Effects of shifts in production on trade patterns

\begin{tabular}{|c|c|c|c|c|}
\hline & $1990-1994(\%)$ & $2000-2004(\%)$ & $2010-2014(\%)$ & $2020-2024(\%)$ \\
\hline \multicolumn{5}{|c|}{ Share of total exports } \\
\hline USA & 70.7 & 47.0 & 42.0 & 35.1 \\
\hline South America & 29.3 & 53.0 & 58.0 & 64.9 \\
\hline \multicolumn{5}{|c|}{ Share of ROW imports } \\
\hline Fall & 19.5 & 30.2 & 34.2 & 35.1 \\
\hline Spring & 80.5 & 69.8 & 65.8 & 64.9 \\
\hline \multicolumn{5}{|c|}{ Share of spring exports } \\
\hline USA & 66.4 & 39.5 & 31.3 & 17.2 \\
\hline South America & 33.6 & 60.5 & 68.7 & 82.8 \\
\hline \multicolumn{5}{|c|}{ Share of fall exports } \\
\hline USA & 88.6 & 64.4 & 62.5 & 63.4 \\
\hline South America & 11.4 & 35.6 & 37.5 & 36.6 \\
\hline \multicolumn{5}{|c|}{ Share of US exports } \\
\hline Fall & 24.4 & 41.4 & 50.9 & 69.9 \\
\hline Spring & 75.6 & 58.6 & 49.1 & 30.1 \\
\hline \multicolumn{5}{|c|}{ Share of South American exports } \\
\hline Fall & 7.6 & 17.2 & 22.1 & 21.8 \\
\hline Spring & 92.4 & 82.8 & 77.9 & 78.2 \\
\hline
\end{tabular}

to less than $25 \%$ in the $2020-2024$ period, $35 \%$ of ROW total imports are estimated to occur in the fall compared to just $20 \%$ in the 1990-1994 period.

In the 1990-1994 period, the USA dominated the soybean trade, accounting for two-thirds of spring exports and almost $89 \%$ of fall exports. Over three-quarters of US exports occurred in spring. By contrast, South American exports occur largely following their harvest in the spring with less than $8 \%$ of total exports occurring in the fall.

Increased ROW imports in the fall and increased South American production in the spring led to a pronounced shift in the pattern of exports from the United States and South America. In the 2020-2024 period, South America dominates the soybean export market in spring, accounting for almost $83 \%$ of global exports. US exports continue to dominate the fall; however, South American exports account for almost $37 \%$ of total trade in the fall compared with only $11 \%$ during the 1990-1994 period.

How do the simulated results compare to empirical data? Figure 4.2 shows the seasonal pattern of actual soybean imports to China from the 2009/2010 to 2013/2014 marketing years. The data mirror the simulated results. While the seasonal import pattern is less pronounced in the empirical data, China, on average, tended to import more soybeans in the second half $(55 \%)$ than in the first half of a year, when domestic crops in China are harvested. Chinese imports from the USA mostly occur following crop harvest in the USA in late fall and continue through to early spring. As the South American crop begins to be harvested in late winter 


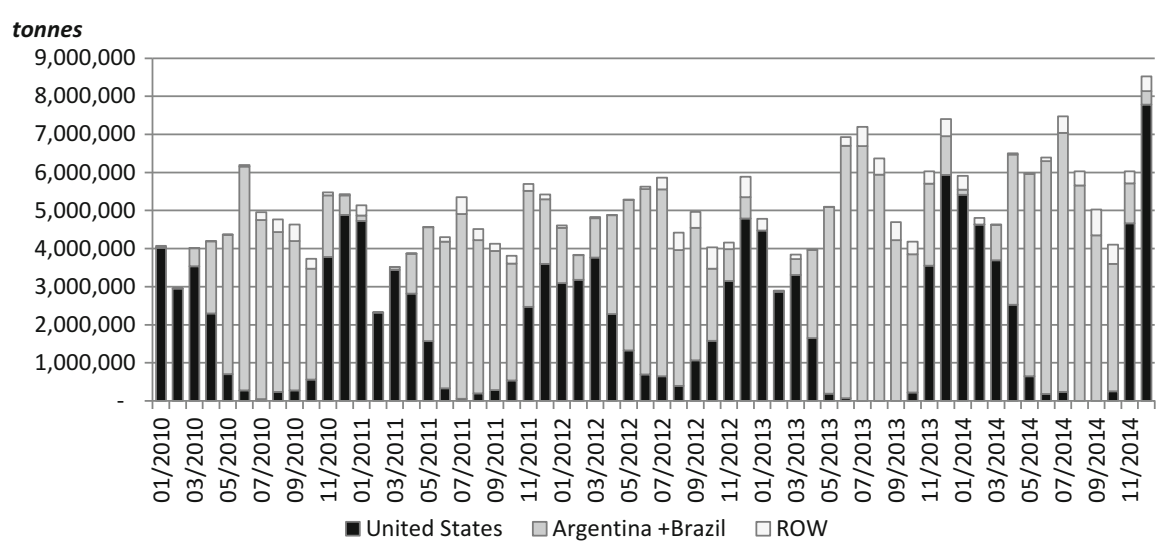

Fig. 4.2 Monthly China soybean imports by origin. Source: Global Trade Information System

and early spring, importers shift their attention to that region as their source of soybeans.

\subsection{Effects of Shifts in Production on Regional Stocks}

As South American soybean production takes up a larger share of global production, a larger share of global stocks are held in that region (Table 4.4). In the 1990-1994 period, US carryout stocks accounted for almost $93 \%$ of global fall carryout stocks. This reflects the fact that production occurs during the fall in the USA, and carryout of old crop soybeans in South America is low. ${ }^{2}$ While South America accounts for the majority of soybean carryout in spring (following harvest), US old crop carryout still accounts for almost $32 \%$ of the total stocks. During the 2020-2024 period, however, South America accounts for over $92 \%$ of the global carryout in spring and $25 \%$ in fall.

With the shift in production from the USA to South America, the time at which global supplies are tightest (measured by the stocks-to-use ratio) shifts as well. In 1990-1994, when US production accounted for the majority of global soybean production, global supplies in late summer (i.e., before harvest of the new US crop) marked the seasonal low point of available soybean supplies in the world. In the simulations, carryout in spring accounted for an average of $48.5 \%$ of the total spring use, while the stocks-to-use ratio in fall averaged $84 \% .^{3}$

\footnotetext{
${ }^{2}$ Here we are talking about speculative stocks, that is, stocks held because the expected return from storing the crop equals or exceeds the costs of storage.

${ }^{3}$ Stocks-to-use ratios are typically calculated as ending stocks as a percent of total annual use. Here, we separate use by period (fall vs. spring) to more accurately reflect available intraseasonal supplies.
} 
Table 4.4 Effects of shifts in production on stocks

\begin{tabular}{l|l|l|l|l}
\hline & $1990-1994(\%)$ & $2000-2004(\%)$ & $2010-2014(\%)$ & $2020-2024(\%)$ \\
\hline \multicolumn{4}{l}{ Share of spring stocks held by } & \multicolumn{4}{l}{} \\
\hline USA & 31.9 & 16.4 & 6.9 & 7.8 \\
\hline South America & 68.1 & 83.6 & 93.1 & 92.2 \\
\hline Share of fall stocks held by & 92.7 & 85.3 & 77.7 & 74.9 \\
\hline USA & 14.7 & 22.3 & 25.1 \\
\hline South America & 7.3 & 58.1 & 60.7 & 63.8 \\
\hline Global stocks to use & 48.5 & 65.6 & 53.7 & 42.8 \\
\hline Spring & 84.1 &
\end{tabular}

\section{1,000 tonnes}

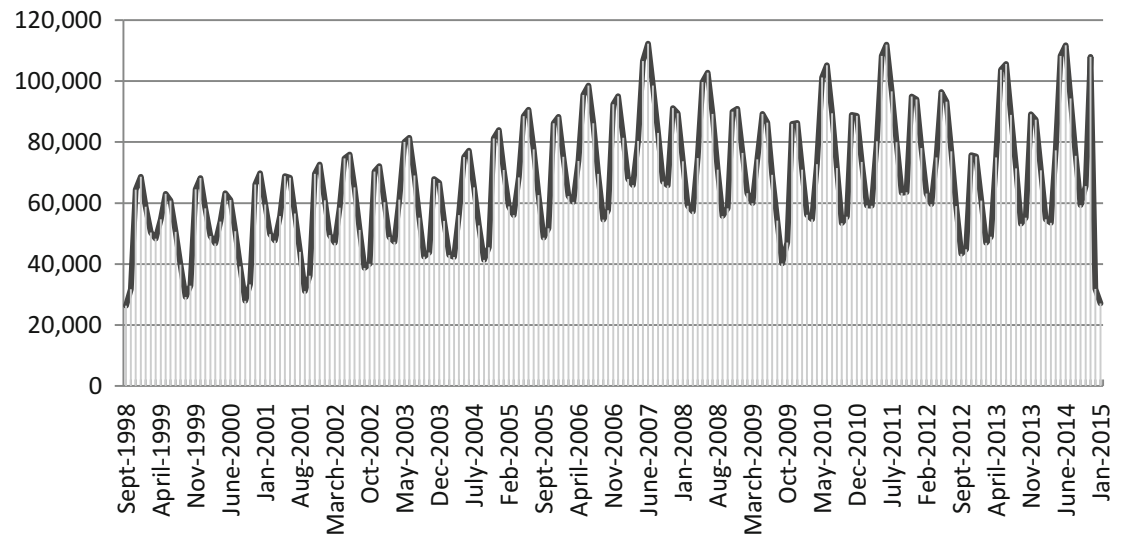

Fig. 4.3 Monthly ending stocks of the major exporters (the USA, Brazil, and Argentina). Source: USDA, based on monthly crush and export numbers from Oil World and Global Trade Information System

As supplies in South America grow, the low point in the year for available supplies is when South American supplies are at their lowest levels, that is to say, at the end of the fall quarter before new crops are harvested. In the simulated results for the period 2020-2024, for example, global fall carryout stocks account for $43 \%$ of total use, while global spring carryout stocks (i.e., just prior to harvest of the US crop) account for $64 \%$ of total use.

Empirical data again support the simulated findings. Figure 4.3 shows soybean stocks in the USA, Brazil, and Argentina from September 1998 to September 2014. ${ }^{4}$ Initially, soybean stocks tended to be lowest in September just prior to the US harvest. Stocks fell throughout winter until the South American crops became available.

\footnotetext{
${ }^{4}$ Monthly soybean stocks were calculated using monthly crush and export numbers. Production was allocated across months based on harvest progress reports from exporting countries.
} 
With the South American harvest, available soybean supplies increased in spring but then fell again to a low point in September. As ROW imports increase in fall, and South American production increases, the pattern becomes more pronounced, with stock levels in March falling to similar (or lower) levels than in September.

The ratio of stock level to consumption is often used as an advanced indicator of abnormal market conditions (see, e.g., Bobenrieth et al. 2013). Typically these metrics are constructed based on northern hemisphere production cycles with carryout stocks measured when northern hemisphere stocks are lowest. Our analysis suggests that, at the very least, such metrics tell only a partial story for crops with significant southern hemisphere production.

\subsection{Effects of Shifts in Production on Soybean Price Integration}

Spatial arbitrage ensures that prices in the exporting countries differ from the world price by the cost of storage (Enke 1951; Samuelson 1952; Takayama and Judge 1971; Fackler and Goodwin 2001). Thus, if transportation costs to the world market are the same in both exporting countries, prices must be the same in both exporting countries, even though they do not trade with each other. This is true, however, only if both exporting countries are guaranteed to export in both periods. If in any period, one country exports, but the other does not, then the link is broken and prices could diverge. The question is whether this is possible or likely.

In the stylized model presented here, we measure the degree to which the prices in one region are linked with prices in the other region with a simple correlation statistic. Table 4.5 shows the correlation between prices in the USA, South America, and the ROW in the fall and spring periods. Note that in the 1990-1994 period, when US exports accounted for $70 \%$ of total global exports, the correlation coefficient for US prices and ROW prices is close to 1 in both the fall and spring periods. South American prices were more closely correlated with the prices in the ROW during the spring period, when the exportable supplies were at their highest level (and they account for about one-third of total world exports). By contrast, South America accounted for just $11 \%$ of the total exports in fall, and the correlation coefficient with the prices in the ROW fell to 0.708 .

Table 4.5 Effects of shifts in production on regional price correlations

\begin{tabular}{l|l|l|l|l}
\hline Region/time period & $1990-1994$ & $2000-2004$ & $2010-2014$ & $2020-2024$ \\
\hline USA-ROW/fall & 0.999 & 0.996 & 0.999 & 1.000 \\
\hline USA-ROW/spring & 1.000 & 0.967 & 0.952 & 0.856 \\
\hline South America-ROW/fall & 0.708 & 0.735 & 0.737 & 0.863 \\
\hline South America-ROW/spring & 0.946 & 1.000 & 1.000 & 1.000 \\
\hline USA-South America/fall & 0.707 & 0.733 & 0.737 & 0.862 \\
\hline USA-South America/spring & 0.946 & 0.967 & 0.952 & 0.856 \\
\hline
\end{tabular}


As South American soybean production increases relative to the USA, US prices remain closely correlated during the fall period. This reflects the fact that US prices remain linked with ROW prices through trade. Recall that by 2020-2024, the US exports almost $70 \%$ of its goods in fall as compared to the 1990-1994 period when over three-quarters of the exports from the USA occurred in spring. The correlation between US and ROW prices falls to 0.856 in the spring reflecting the fact that the USA is uncompetitive in ROW markets. With South America emerging as the dominant supplier to the ROW in the spring period (accounting for $83 \%$ of total exports), the correlation between prices in South America and the ROW is 1.0.

Figure 4.4a shows that monthly export prices of soybeans from the USA, Brazil, and Argentina were closely correlated between 1990 and 2014. The simple correlation matrix suggests correlation coefficients of 0.99 or higher for the three time periods. Expressing the US Gulf price as a percentage of the prices in Brazil or Argentina, however, reveals a more seasonal pattern: US prices tend to fall relative

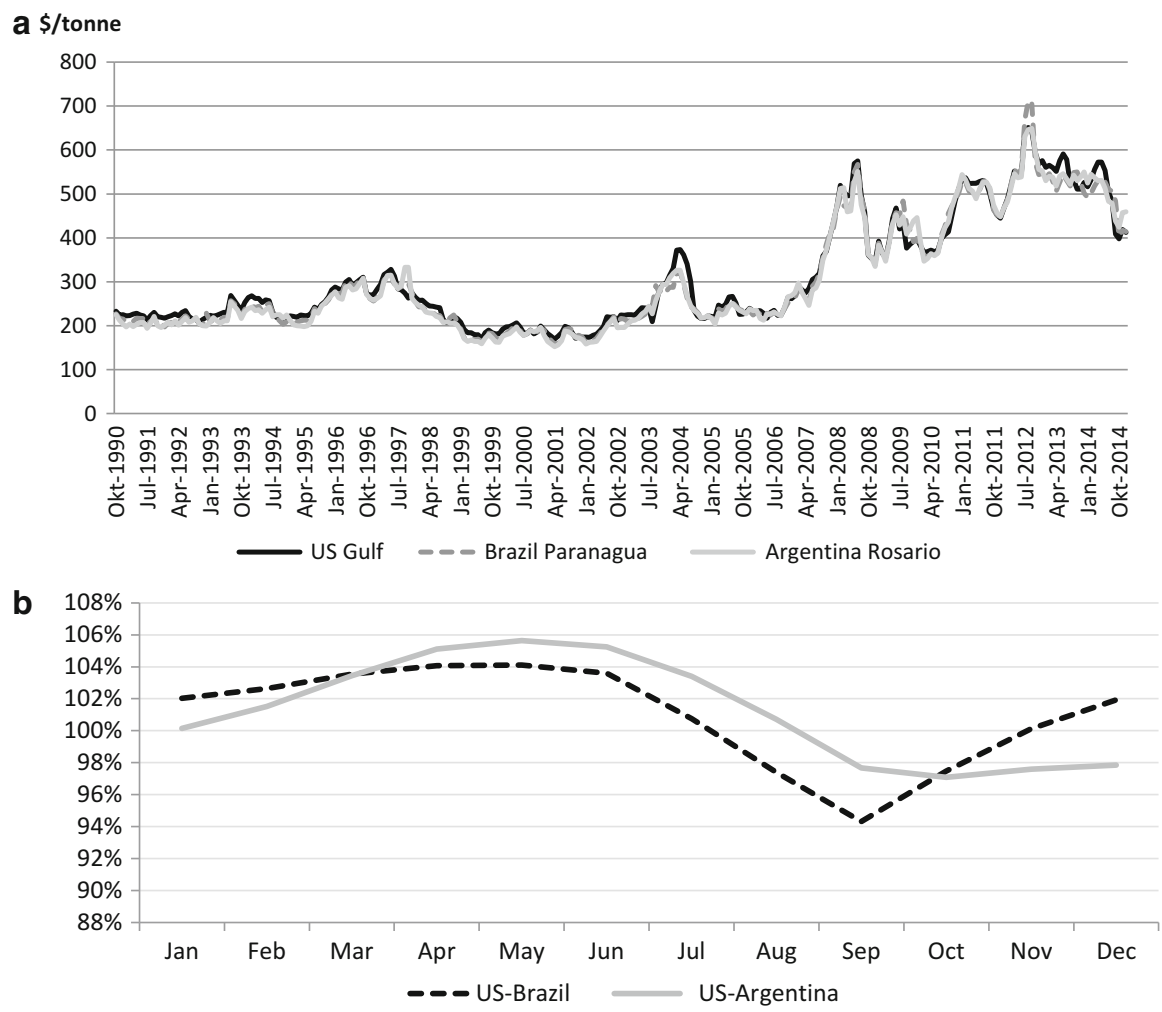

Fig. 4.4 (a) Soybean export prices. Source: USDA, Foreign Agricultural Service, Oilseeds: World Markets and Trade. (b) US price as a percentage of prices in Brazil and Argentina, average 20052014. Source: USDA, Foreign Agricultural Service, Oilseeds: World Markets and Trade 
to southern hemisphere prices in fall, during harvest time in the USA, and rise in spring, during harvest time in the southern hemisphere (Fig. 4.4b).

A large body of literature has emerged that has examined price movements to test market efficiency and the degree to which markets are integrated (see Ravallion 1986; Mundlak and Larson 1992; Fackler and Goodwin 2001; Fackler and Tastan 2008). These studies have used time series and other empirical methods to examine how tariffs, transportation costs, exchange rates, and other transaction costs affect market integration. Our analysis suggests that intraseasonal timing of production is also an important factor. Previous studies about the soybean market noted how the seasonal aspect of soybean production affects price transmission between southern and northern hemispheres' producers and import markets, such as the EU (Margarido et al. 2007; Machado and Margarido 2004).

\subsection{Carrying Costs Among Northern and Southern Exporters}

In a market determined by one supplier, prices tend to rise throughout the marketing year, reflecting the costs of holding the crop over a period of time (Lowry et al. 1987; Miranda and Glauber 1993; Williams and Wright 1991). Those carrying costs can be indirectly measured by examining the spread between futures contracts (Williams 1986). In this paper, futures spreads are constructed using closing futures prices from the Chicago Mercantile Exchange (CME), the Bolsa de Comercio in Rosario, Argentina (Bolsa), and the Dalian Commodity Exchange in China (DCE). To compare the array of futures prices at a given point in time, we averaged the daily closing futures prices in October of each year sampled for the November through September futures contracts. To compare the contracts across time and exchanges, we normalized the spreads by expressing all of the contracts in terms of the November contract.

Figure 4.5a shows the spreads for CME soybean futures. For the most part, the spreads exhibit the expected pattern: future contracts show positive carrying charges through the marketing year, reflecting carrying costs. As the arrival of new crops on the market approaches, prices weaken and can show negative carrying costs (often referred to as backwardation). The exceptions to this pattern are the 2012/2013 and 2013/2014 marketing years, which were characterized by tight US supplies following the drought in 2012 and large expected harvests in South America. As a result, futures contracts exhibit backwardation throughout the marketing year. That pattern reverted to the more typical pattern in 2014/2015 following the large soybean harvest in the USA and the rebuilding of US soybean stocks.

Consistent with results from the storage model, closing prices in Argentina for the same period reflect the fact that southern hemisphere harvest starts 6 months after the northern hemisphere harvest (Fig. 4.5b). Bolsa futures show backwardation from November through May and subsequently positive carry in the months following harvest. The pattern resembles that of the CME, except out of phase by 6 months. 

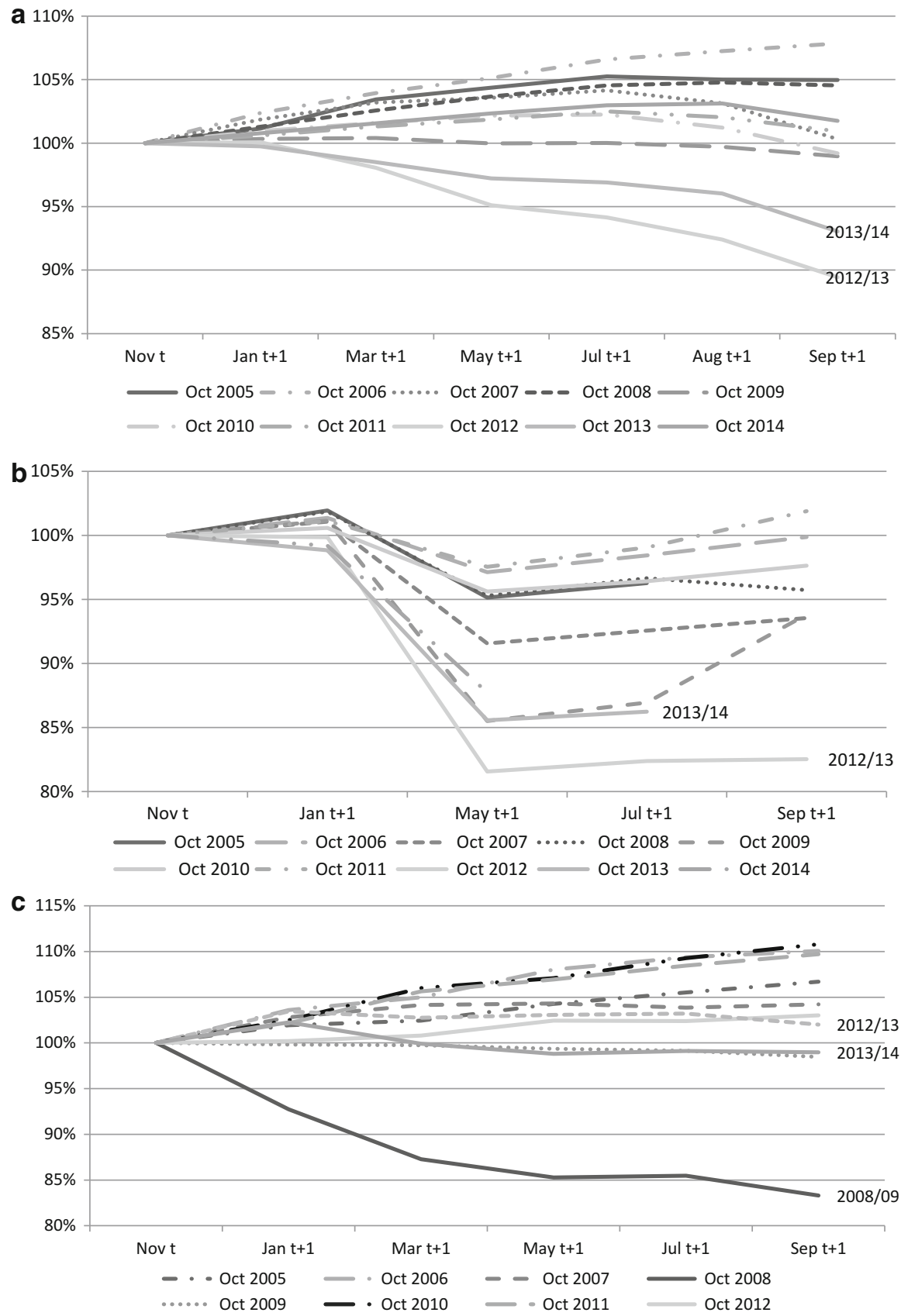

Fig. 4.5 (a) Soybean futures-Chicago Mercantile Exchange. Source: Chicago Mercantile Exchange. (b) Soybean futures-Bolsa de Comercio de Rosario. Source: Bolsa de Comercio de Rosario (Argentina). (c) Soybean futures-Dalian Commodity Exchange. Source: Dalian Commodity Exchange (China) 
Figure 4.5c shows the same array for DCE futures taken from the same period. As discussed earlier (Fig. 4.2), China largely imports soybeans from the USA in the first part of their marketing year and then switches to importing from the southern hemisphere after crops are harvested there. All else equal, one would expect that there would not be large incentives to store since one could purchase lower cost soybeans when new supplies become available in the other hemisphere. Many of the years in the limited data sample exhibited this pattern (e.g., 2007, 2009, 2012, 2013, and 2014). In some of the years considered here (2005, 2006, 2010, and 2011), the pattern of DCE futures exhibited a similar pattern to that of CME, with futures showing positive carry throughout the marketing year. Lastly, backwardation was present throughout the 2008/2009 market year.

Two factors may help explain the anomalies. First, China's domestic soybean consumption grew by over $8 \%$ annually over 2005-2014; imports grew annually by $11 \%$ over the same period. Strong carrying charges may reflect, in part, the demand for current supplies to meet future consumption. Second, China introduced a price support for soybeans beginning 2008 to keep market prices high throughout the marketing year (Gale 2013). From 2009 to 2012, soybean support prices were raised steadily. While the Chinese authorities have signaled their intent to experiment with more direct (income) support measures that allow prices to be determined by market forces, price supports continue to have the potential of distorting intraseasonal price relationships.

\subsection{Effects of Production Shifts on Price Variability}

How has the production growth in the southern hemisphere affected price variability? Assuming yields are uncorrelated between northern and southern hemispheres, global exporter yield variability could be expected to decline when production in the southern hemisphere approaches levels similar to those in the USA. Lower production variability would mean more stable prices. However, in the scenarios considered here, those effects are likely to be small. Figure 4.6 shows how global exporter yield variability is affected by the share of production from southern hemisphere exporters. From 1990 to 1994, South America accounted for about $38 \%$ of total production among global exporters. By around 2020-2024, South America is projected to account for almost two-thirds of production among global exporters. Within this range, global yield variability in exporting regions does not vary much (Fig. 4.6).

Nonetheless, shifts in production are estimated to have profound effects on intraseasonal price variability in importing and exporting regions. Table 4.6 shows the simulated standard deviation of prices in the fall and spring periods in the three regions. For the exporting countries, prices are more volatile in the second half of their crop year, when supplies are tighter; this result is consistent with the findings of Lowry et al. (1987).

Price variability in the ROW is largely tied to price variability in exporting regions. During the 1990-1994 period, in which the USA accounted for over $70 \%$ 


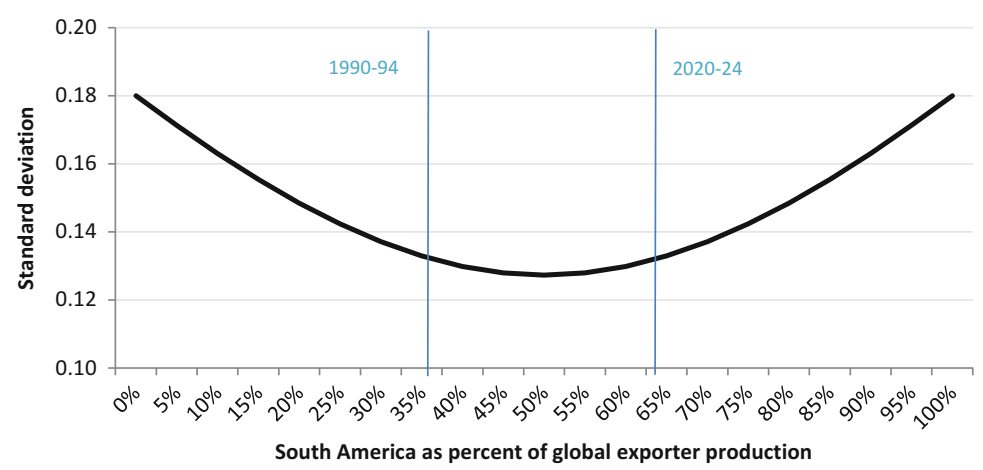

Fig. 4.6 Annual yield variability of major exporting countries. Note. The standard deviation of normalized yields in South America and the USA are assumed equal to 0.18 (Table 4.1)

Table 4.6 Effects of shifts in production on price variability

\begin{tabular}{l|l|l|l|l}
\hline & $1990-1994$ & $2000-2004$ & $2010-2014$ & $2020-2024$ \\
\cline { 2 - 5 } & \multicolumn{5}{l}{ Standard deviation } \\
\hline USA & \multicolumn{5}{l}{} \\
\hline Spring & 0.332 & 0.342 & 0.363 & 0.406 \\
\hline Fall & 0.254 & 0.230 & 0.244 & 0.318 \\
\hline South America \\
\hline Spring & 0.341 & 0.321 & 0.342 & 0.348 \\
\hline Fall & 0.400 & 0.419 & 0.439 & 0.411 \\
\hline ROW & & & \\
\hline Spring & 0.332 & 0.321 & 0.342 & 0.348 \\
\hline Fall & 0.254 & 0.233 & 0.245 & 0.320
\end{tabular}

of global exports and was the dominant exporter in both spring and fall, ROW price variability is roughly equal to US price variability (as measured by the standard deviation). Because of this, price variability in the ROW tends to be higher in spring than fall. As the ROW becomes more reliant on imports from South America in the spring period (almost $83 \%$ by 2020-2024 compared with $34 \%$ in 1990-1994), ROW spring price variability is tied to its counterpart in South America. ROW price variability continues to be tied to its counterpart in the USA in fall, during which the USA supplies the majority of exports to the ROW. The simulation results suggest a small increase in price variability over the 30 -year period which may reflect, in part, the increasing reliance on imports to meet the consumption in the ROW.

Lastly, as mentioned earlier, production is assumed to be exogenous with respect to price in our stylized model. In models with price-responsive supply, a supply shock in one region would affect plantings in the other region, allowing for more rapid adjustment (see, e.g., Haile et al. 2014; Lybbert et al. 2014). When such models are applied to the sample, the growth of South American production would likely show a more significant role in reducing price volatility. 


\subsection{Conclusions}

The growth of southern hemisphere production has increased global supplies of grains and oilseeds, helping to meet the large growth in global demand witnessed in the past 30 years. The structural model presented in this paper gives important insights into intraseasonal patterns of storage, trade, and market prices that have accompanied the growth in southern hemisphere production, patterns that are generally not captured in annual models. Applying the model to the global soybean market, we show how increased production share in the southern hemisphere has resulted in more pronounced seasonality in exports between exporters in the northern and southern hemispheres. The analysis also suggests that the shift in production means that from a global perspective, the crop "season" has shortened from 12 to 6 months. With a new crop available every 6 months, stock levels in March are as relevant as those in September in indicating supply availability. While trade and storage link market prices across time and space, the analysis suggests that seasonal trade patterns can also disrupt price integration or, more accurately, result in a more seasonal pattern of integration. Failure to recognize those patterns can obscure and bias analyses of global food security, potentially exaggerating the impact of shortages or surpluses when they occur in one hemisphere but not in the other.

Open Access This chapter is distributed under the terms of the Creative Commons AttributionNoncommercial 2.5 License (http://creativecommons.org/licenses/by-nc/2.5/) which permits any noncommercial use, distribution, and reproduction in any medium, provided the original author(s) and source are credited.

The images or other third party material in this chapter are included in the work's Creative Commons license, unless indicated otherwise in the credit line; if such material is not included in the work's Creative Commons license and the respective action is not permitted by statutory regulation, users will need to obtain permission from the license holder to duplicate, adapt or reproduce the material.

\section{References}

Alexandratos N, Bruinsma J (2012) World agriculture towards 2030/2050: the 2012 revision. Agricultural Development Economics Division. Food and Agricultural Organization of the United Nations. ESA Working Paper No. 12-03

Bobenrieth E, Wright B, Zeng D (2013) Stocks-to-use ratios and prices as indicators of vulnerability to spikes in global cereal markets. Agric Econ 44(s1):43-52

Bruinsma J (2011) The resource outlook to 2050: by how much do land, water use, and crop yields need to increase by 2050? In: Confroti P (ed) Looking ahead in world food and agriculture: perspectives to 2050. Rome, FAO

Enke S (1951) Equilibrium among spatially separated markets: solution by electrical analogue. Econometrica 19(1):40-7

Fackler P, Goodwin B (2001) Spatial price analysis. In: Gardner B, Rausser G (eds) Handbook of agricultural economics, vol 1B. Elsevier, Amsterdam

Fackler P, Tastan H (2008) Estimating the degree of market integration. Am J Agric Econ 90(1): $69-85$ 
Food and Agricultural Policy Research Institute (FAPRI) (2014) U.S. baseline briefing book. FAPRI-MU Report \#02-14. Available at http://www.fapri.missouri.edu

Gale F (2013) Growth and evolution in China's support policies. Economic Research Service, US Department of Agriculture. Economic Research Report No. 153, Aug 2013

Haile MG, Kahkuhl M, von Braun J (2014) Inter- and intra-seasonal crop acreage response to international food prices and implications for volatility. Agric Econ 45(2014):693-710

Lowry M, Glauber J, Miranda M, Helmberger P (1987) Pricing and storage of field crops: a quarterly model applied to soybeans. Am J Agric Econ 69:740-749

Lybbert TJ, Smith A, Sumner DA (2014) Weather shocks and inter-hemispheric supply responses: implications for climate change effects on global food markets. Clim Change Econ 5(4): 1450010

Machado L, Margarido M (2004) Evidences of seasonal price transmission in soybean international market. La Econ Aplicada 8(1):127-141

Margarido M, Turolla F, Bueno C (2007) The world market for soybeans: price transmission into Brazil and effects from the timing of crop and trade. Nova Econ 17(2):1-19

Miranda M, Glauber J (1993) Estimation of intra-seasonal demand for fall potatoes under rational expectations. Am J Agric Econ 74:104-112

Miranda M, Fackler P (2002) Applied computational economics and finance. MIT Press, Cambridge, MA

Mundlak Y, Larson D (1992) On the transmission of world agricultural prices. World Bank Econ Rev 6(3):399-422

OECD-FAO (2014) OECD-FAO agricultural outlook 2014-23. Available at http://www.agrioutlook.org/publication.html

Ravallion M (1986) Testing market integration. Am J Agric Econ 68(1):102-9

Samuelson P (1952) Spatial price equilibrium and linear programming. Am Econ Rev 42(3):283303

Takayama T, Judge G (1971) Spatial and temporal price allocation models. North-Holland, Amsterdam

U.S. Department of Agriculture (USDA) (2015) 2015 International long-term projections to 2024. Available at http://www.ers.usda.gov/data-products/international-baseline-data.aspx

Williams JC (1986) The economic function of futures markets. Cambridge University Press, Cambridge

Williams JC, Wright BD (1991) Storage and commodity markets. Cambridge University Press, Cambridge 